\title{
Treasury Single Account And Financial Discipline: A Causality Analysis
}

BY

Sunday A. Effiong*

Department of Accounting, Faculty of Management Sciences, University of Calabar, P.M.B. 1115, Calabar, Cross River State, Nigeria. drsunnyeffi@yahoo.com

\section{Okoi, John Obono}

Department of Accounting, Faculty of Management Sciences, University of Calabar, P.M.B. 1115, Calabar, Cross River State, Nigeria. Johnokoi75@gmail.com

\section{Nwafor Chidi Benson}

Department of Accounting, Faculty of Management Sciences, University of Calabar, P.M.B. 1115, Calabar, Cross River State, Nigeria. chidibenson@yahoo.com

$\&$

Ahakiri, F. Idiege

Department of Accounting, Faculty of Management Sciences, University of Calabar, P.M.B. 1115, Calabar, Cross River State, Nigeria. ahakirifrancis.1@gmail.com

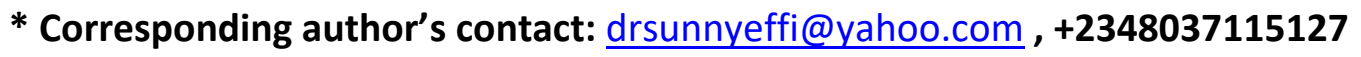




\begin{abstract}
Government revenue is the most critical variable that determines the level of expenditure, investment and growth of the economy. This study assessed the pre government revenue and the post government revenue generation outcomes using Treasury Single Account's effective year of implementation as the baseline in Nigeria. The study sought to assess whether or not government revenue had changed significantly on the adoption of TSA. To drive this objective, government revenues were collated for 2010 - 2014 (pre TSA) and 2015-2019 (post TSA) from the Statistical Bulletin of the Central Bank of Nigeria. The study applied the paired sampled t-test to determine whether or not government revenue had increased significantly in the post TSA years of adoption. Findings showed that there is a significant increase in government revenue after the adoption of TSA in Nigeria. Following this finding, the study recommended that internal control system should be strengthened in government Ministries and Parastatals to forestall revenue leakages, and that public servants should be properly trained on the efficient application of TAS software. Also, the federal government should put in place Budget Monitoring Group to constantly monitor revenue targets and control expenditure limits.
\end{abstract}

Keywords: Treasury Single Account, Pre TSA, Post TSA, Government revenue, Financial discipline, Government Expenditure. 


\subsection{INTRODUCTION}

Treasury Single Account (TSA) is a process where revenues and income are channeled to a unified account of government. The policy is aimed at accountability, transparency and prevention of misappropriation of funds. The advent of Treasury Single Account (TSA) emanated from how funds were managed in various Deposit Money Banks (Adeolu, 2015). Many countries are focus on financial balances to ensure that resources are effectively, efficiently and prudently used. When there is an improvement on how resources are used, it promotes government reform agenda and leads to budget reduction which will always increase the value of money. According to Yusuf \& Chiejina (2015), in adopting TSA, all revenues received on behalf of the federation is deposited as a unified account. It aids the banking industry to execute policies that are regulated by the government (Okwe, Chijioke, Temiloluwa, \& David, 2015). Furthermore, government revenues are sent to a centralized account in accordance with 1999 Constitution, as amended. Based on constitutional provision, government ministries pay a percentage of their expected income into a unified account. These constitutional directives are however applicable to other agencies where the introduction of the new policy in 2015 depicts a retirement of revenues implemented by the authority as a single unit (CBN, 2015). The aim of the new policy thrust is to control government finances and also optimize government cash management. This account is devoid of borrowing and payment of interests that are 
charged on expenditure of agencies. In this process, idle balances are not kept in the custody of the commercial banks.

\subsection{The Concept of Treasury Single Account and Treasury Single Account Policy}

Treasury Single Account (TSA), as a government structure, is a requisite for the current policy as regards the management of government cash for the purpose of unifying all income into one account in order to have a clear understanding of the sources and allocation of funds. Pattanayak and Fainborn (2010) and Yusuf \& Chiejina (2015), viewed the entire structure of Treasury Single Account (TSA) as formulated based on three fundamental structures of integrating banking standards that will enable the Federal Ministry of Finance to carry out its supervisory role, and monitor the management of cash, and the in and out transactions in the treasury. This is intended to discourage the maintenance and operation of a plethora of bank accounts by government ministries and agencies, with the emphasis that the Treasury Single account (TSA) can only be accessed following established procedures together with the various budgetary provisions. Shah (2007), examined these procedures and suggested that aggregated government funds, whether the funds are part of the budgetary control or not, should be transferred to the Treasury Single Account (TSA). Also, Nelson, Adeoye \& Ogah (2015), viewed TSA to be meant for Ministries, Departments/Agencies (MDAs) where all account balances are kept and the apex bank exercises control. They 
opined that it is a linked account operated by all MDAs that clearly shows various debit and credit transactions with monetary authorities. Onyekpere (2015), explained that it is a single structured consolidated record that collects all other accounts into one account that all government cash funds are kept and managed effectively. Furthermore, it gives clear understanding of all inflows and outflows at a glance. In the same vain, Chukwu (2015), in his opinion, stated that Treasury Single account (TSA) being government consolidated structure, brings together all parastatals having a centralized account showing how transactions were carried out with the Deposit Money Banks (DMBs), detailing every business operation, closing balances at the end, and transfers to the account of the apex bank. It plays a pivotal role by linking accounts of commercial banks to central accounts so that transactions activities can be monitored on daily basis, and closing balances with other agencies are transferred to the central account. The MDAs also maintain personal accounts for daily receipts and payments, where closing balances are transferred to the monetary authorities, (Chuckwu 2015).

\subsection{Empirical perspective of TSA literatures}

Muraina (2018) conducted a study on TSA and banks' liquidity. He employed correlation research design. The study revealed that fixed deposit affected banks' liquidity. It was recommended that Nigerians banks should have adequate cash reserve to cushion the effect of TSA transactions to engender growth in the sector. 
Igbokwe-Ibeto, Nkomah, Osakede, and Kinge, (2019) investigated TSA and accountability in Nigeria. The objective was to determine the role of TSA in government sector. Data were extracted using questionnaire instrument, and Pearson product moment correlation was used to establish how these variables relate. The results confirmed that there is a significant correlation between TSA policy and accountability indicators. Ejoh (2020) conducted a study on TSA and Government Revenue in Nigeria, with a focus on public monies. Descriptive survey design was embraced and the data were analyzed using simple regression. Results indicated that TSA is positively significant on cash control.

Oladipupo, Olatunbosun and Talabi (2019) conducted a pre/post study on TSA and performance. Purposive sampling method was used and data were collated on profitability of banks. It was discovered that TSA positively affected profitability. It was recommended that managers in the banking sector should devise strategies that will allow the sector go in tandem with their ethics. Oluyinka, Omowumi, and Adebola, (2021) studied TSA policy and Revenue generation in Nigeria. Descriptive statistical method with inferential analysis was adopted. Based on the results, TSA does not influence the government generated revenue. It was recommended that policy makers should adequately monitor the operations of the treasury single account.

Effiong and Obun (2020), in their study emphasized on Post TSA effect on revenue, job creation as well as improved living condition. Ex-post facto research 
design and secondary data were employed for analysis and testing. The data were sourced from statistical records using multiple regression. The findings showed that TSA is significantly related with GDP. According to descriptive statistics result, non- oil revenue generation was significant. It was concluded that the growth of the economy is affected positively and negatively. The study therefore, recommended immediate promulgation of a law to give legal backing that will improve revenue generation to meet up with government bills.

\subsection{Theoretical perspective of TSA framework}

Accountability theory was originated by Vance, Lowry \& Egget in 2013. They posit that accountability captures one's behavior on the aspect of the other, and how he or she is accountable to a particular behavior. This theory depicts accountability in the way the Federal government uses information to link with Ministries, Departments and Agencies in the collection and remittance of funds collected on behalf of the government. This theory is anchored on implementation of transparency policy which informs why it was instituted in the public sector.

The Diffusion of Innovation theory was propounded by Rogers in 1995 . He portrayed diffusion theory as an avenue through which ideas are communicated over a given period to a specified area. The theory was postulated based on four cardinal points such as innovation, regular communication, time and society. The concern of diffusion theory is to exchange fresh ideas etc. on persons and companies with their ideas and plans. Such attitude is basically as a result of uncertainty of the value or quality in deciding the modern way of doing things in 
place of the old. According to Rogers, the new idea introduced and the uncertainty were relevant, and is an essential feature of innovation in decision making. The importance of this theory is anchored on facts essential for the formulation of the policy, thus the decision by government to uphold ideas or principles that will improve transparency as well as improve the economy.

The Modern Monetary theory is anchored on actions and acts of an independent nation in managing public funds. Udo and Esara (2016) supported this policy where government generated funds are domiciled with the apex bank. Also, Eric \& Wray (2013), affirmed that government should take into consideration any transaction carried out with non-governmental sectors, and should be declared official secret which should be available only to authorized persons.

\subsection{METHODOLOGY}

The study made use of ex-post facto research design, employing secondary data for the analyses and testing of the research hypotheses. The data were sourced from the Central Bank statistical bulletin and divided into two equal samples, namely, pre-TSA revenue, 2010 - 2014 and post-TSA revenue, 2015- 2019. The paired samples test was the analytical technique for this study. Data were then collected for the two samples, and then tested for significance using the paired sample of independent t-test technique. This technique is commonly applied in case-control studies or repeated-measures designs where a pre and post analyses is required. 


\subsection{Model specification}

The basis for data analysis was the paired sample t-test. The paired sample t-test analytical technique could be modelled using the formula:

$t=\frac{\bar{x}_{\text {diff }}-0}{S_{\bar{x}}}$

But,

$S_{\bar{x}}=\frac{S_{\text {diff }}}{\sqrt{n}}$

Where:

$\bar{x}_{\text {diff }}=$ Sample mean of the differences

$\mathrm{n}=$ Sample size (i.e., number of observations, in our case 14 years, for each of the pair)

$S_{\text {diff }}=$ Sample standard deviation of the differences

$S_{\bar{x}}=$ Estimated standard error of the mean $(s / \operatorname{sqrt}(n))$

It must be understood that the estimates were generated automatically using the SPSS software. The calculated $t$-values were compared with critical $t$-values at $\mathrm{df}$ $=n-1$ with 95 per cent confidence level.

\subsection{RESULTS AND DISCUSSIONS}

To determine effect of TSA policy on government revenue generation capacity, and the level of financial discipline, the data collected from the CBN statistical bulletin were plotted for visualization thus: 


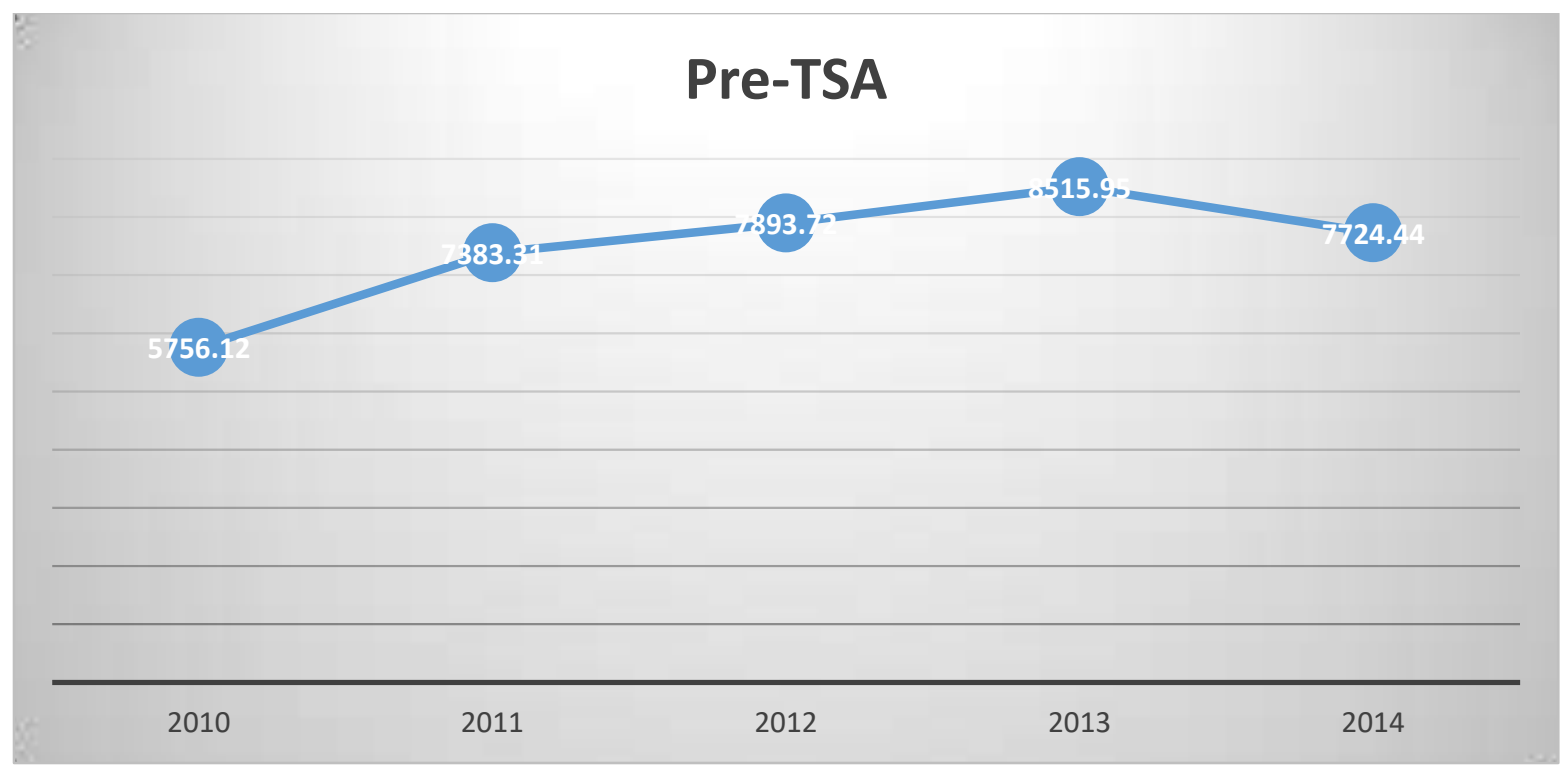

Figure 1: Pre-TSA Revenue profile (Source: CBN Statistical Bulletin, volume 30, 2019).

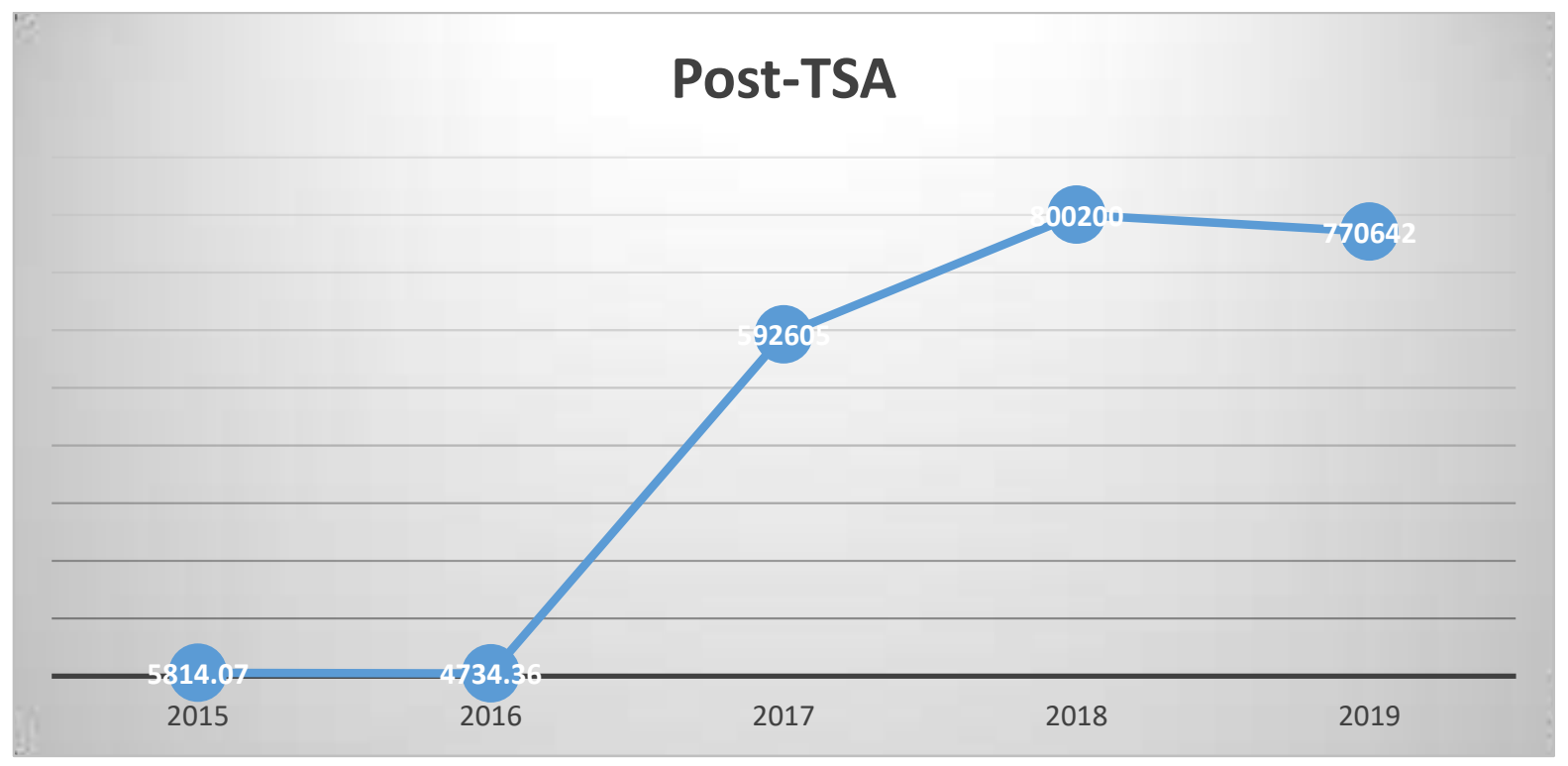

Figure 2: Post-TSA revenue profile. (Source: CBN Statistical Bulletin, volume 30, 2019). 


\begin{tabular}{ll|r|r|r|r|r|r|r|r}
\hline Pa & PreTSA_R & 8472.8 & 1795.99 & 803.193 & 6242.8162 & 10702.8 & 10. & 4 & .000 \\
$\begin{array}{l}\text { ir } \\
\text { ev - } \\
\begin{array}{l}\text { PostTSA_ } \\
\text { Rev }\end{array}\end{array}$ & 3929 & 555 & 363 & 6 & 6231 & 549 & & \\
\hline
\end{tabular}

From Table 3, it is clear that the average value of pre and post TSA revenue was 8472.84. The standard deviation of the data set was 1795.99 further away from the mean value. The t-value of 10.549 with its corresponding $\mathrm{P}$-value less than 5 per cent implied that post TSA revenue had significantly improved financial discipline relative to the pre-TSA revenue. This implied that government post TSA revenue and policy had significantly improved financial discipline relative to the pre-TSA revenue policy. The mean standard error of 803.19 showed that approximately post TSA revenue of government had differed from the pre-TSA revenue by 803.19 billion naira.

\subsection{DISCUSSIONS}

Based on the results, post-TSA revenue increased significantly above the pre-TSA government revenue. This implies that TSA policy is highly significant and relevant in enforcing financial discipline in the public sector entities. Government revenue generation in Nigeria has increase sufficiently with the introduction of TSA. MDAs had generated more revenue in the post-TSA era than pre-TSA. This is because leakages in revenue has been blocked by the introduction of TSA. This finding is supported by Yusuf (2016), who studied the effect of the new policy in blocking leakages to enhance effectiveness. His results showed that TSA enhances 
government revenue through blockage of leakages, promoting financial discipline/transparency and enhancing accountability in government finances. The results of this study corroborates the findings of Effiong, Oro, Ogar, Imong, Jacob, \& Orim (2017) who discovered that fraud management before the introduction of TSA, IPPIS and IFMIS was not effectively handled, and that Fraud has been on the increase before the introduction of TSA, and that there is a positive relationship between TSA, IPPIS and IFMIS and Fraud management.

\subsection{CONCLUSION AND RECOMMENDATIONS}

Going by the results of the study, the new policy on Treasury Single Account significantly influenced financial discipline and revenue generation in Nigeria. The implication of this is that the introduction of TSA had enhanced the operational efficiency of government agencies, reduced the level of fraud and regulated the spending pattern of MDAs, enhancing the capacity to generate more revenue in Nigeria. Going by the findings, this study recommends that internal control system MDAs should be properly guided and strengthening for effective realization of full potentials of TSA. Also, working condition of staff should be effectively improved to enhance workers' dedication to the goals of TSA. Loopholes in financial management system should be closed rather through strong internal control mechanisms. 


\section{REFERENCES}

Adeolu, I. A. (2015). Understanding the treasury single account (TSA) system things you should know. Business \& Economy, Market Development. Abuja: Office of the Accountant General of the Federation.

Central Bank of Nigeria (2015). Revised guidelines for compliance with treasury single account by banks in Nigeria, Abuja: CBN.

Chukwu, I. (2015). Can treasury single account (TSA) work in Nigeria? Vanguard Newspaper Editorial, 16, 33-35

Effiong, S. A., \& Obun, D. N. (2020). Treasury single account \& economic growth: asymptomatic evaluation. Journal of Critical Reviews, 7(13), 1396 - 1406.

Effiong, S. A., Oro, B. L., Ogar, G. U., Imong, N. R., Jacob, G. E., \& Orim, B. I. (2017). Treasury single account (TSA), Integrated payroll and personnel information system (IPPIS) \& Integrated financial management information system (IFMIS): application and implementation effects on fraud management in Public sector in Nigeria. IOSR Journal of Business and Management, 19(8) version $7,22-30$.

Ejoh, N. O. (2020). Treasury Single Account (TSA) Implications on Government Revenue Control Among Federal Government Parastatals in Nigeria. IOSR Journal of Economics and Finance, 11(1), 18 - 25

Eric, J. U., \& Wray, E. E. (2013). Adoption of treasury single account (TSA) by State governments of Nigeria: benefits, challenges and prospects. Journal of Finance and Accounting, 4(30), 126-130

Igbokwe-Ibeto, C. J. Nkomah, B. B. Osakede, K. O. \& Kinge, R. F. (2019). Treasury Single Account - Transparency and Accountability in Public Finance Management in Nigeria: the journey so far. International Journal of Social and 
Management Research, 4(1), 1-11

Muraina, S. A. (2018). Effect of Treasury Single Account (TSA) on deposit money banks' liquidity performance in Nigeria. International Journal of Family Business and Management, 2(2), 1-15.

Nelson, I. E., Adeoye, U. B., \& Ogah, R. H. (2015). Public Sector Accounting and Finance control. Arabia Journal of business and Management Review, 1(6), 221245

Okwe, A., Chijioke, N., Temiloluwa. A., \& David. O. (2015). Treasury single account: giving life to Jonathan's 'dead' policy directives. The Guardian, 52-58.

Oladipupo F., Olatunbosun O. \& Talabi A.,(2019).Impact of treasury single account (TSA) on the financial performance of deposit money banks (DMBs) in Nigeria: a pre-post analysis. Open Journal of Social Sciences, 7(5), 66 - 79.

Oluyinka O., Omowumi O. O., \& Adebola, D. K. (2021). Treasury single account policy and revenue generation among federal parastatals in Ekiti-State, Nigeria. Online Journal of Social Sciences Research, 5, 6-12

Onyekpere, N. N. (2015). Public policy: effects of treasury single account (TSA) on Nigerian banks. Vanguard Newspaper Editorial, 14(15), 5 - 6.

Pattanayak, C. O., \& Fainborn, M. C. (2010). Efficiency and accountability of public sector revenue and expenditure in Nigeria (1970-2014). European Journal of Accounting, Auditing, and Finance Research. 4(7), 23 - 42.

Shah, P. (2007). Treasury single account: an essential tool for government cash management, Fiscal affairs department (IMF working paper). Understanding the treasury single account system: things you should know, retrieved on August 17, 2021, from www.systemspace.com 
Udoh, U. A., \& Esara, Y. K. (2016). Implementation of treasury single account and Nigerian economy. Business and Economy, market development and reports, 4(5), $20-36$.

Vance, A., Lowry, P. B. \& Egget, D. (2013). Using accountability to reduce access policy violations in information system. Journal of management Information System, 10(1), 23-45

Yusuf, I.A., \& Chiejina, N. (2015). Anti-Graft War: One Economy, One Account. The Nation, August 16, 9-10 \&71. 